\title{
Fabelvejen mod nord
}

\section{Merethe Lindstrøms Nord (2017) som besjælet dystopi}

\author{
SF refer [s] to phenomena that can neither be photographed \\ nor represented in straightforward prose. \\ Seo-Young Chu: Do Metaphors Dream of Literal Sleep? A \\ Science-Fictional Theory of Representation (s. 53)
}

De mange forskellige genremærkater - science fiction (herefter sf), dystopi, postapokalypse, historisk roman, krigstraume eller økokritisk samtidsroman - som norske litteraturkritikere satte på Merethe Lindstrøms seneste roman Nord (2017), angiver ganske vist bogens potentielle tematikker og læsepositioner, men til kritikernes frustration var romanen for mærkelig til, at de kunne etablere entydige læsninger. Aftenpostens anmelder Kenneth Moe stillede spørgsmålet, om romanen havde "vært bedre om den var dårligere?" (Moe 2017). Spørgsmålet er ikke helt så tåbeligt, som det lyder. Det, Moe efterlyser, er en tydeligere forankring i samtidskulturen og en skarpere ideologisk kritik, altså dystopiens mest anvendte valuta: det allegoriske spil mellem primær- og subtekst, hvor tendenser i forfatterens samtid udsættes for satire og kritik gennem beskrivelsen af et fiktionaliseret samfund, og hvor fremskrivningen af disse tendenser gør læseren i stand til at se sig selv og sin egen kultur på en fremmedgjort og anderledes måde.

En sådan kritik indebærer forventningen om en politiserende tendens i romanen, noget genkendeligt i det fremmede og fiktionaliserede, hvor tekstens egentlige betydning findes, som vi kender det fra dystopi-traditionens kanoniserede værker: Jevgenij Zamjatin og George Orwell angriber totalitarismens overvågningsdiktatur i henholdsvis Vi (1921) og Nineteen Eighty-four (1948), Henry Fords industrialisering kritiseres i Aldous Huxleys Brave New World (1932), og der advares mod Europas gryende fascisme og nazisme i Karin Boyes Kallocain (1940). Nord har ikke en sådan tydelig eller entydig subtekst. I stedet er den, som sin forgænger Fra Vinterarkiverne (2015), som måske nok er Lindstrøms mest selvbiografiske og personlige roman, af en mere diffus karakter. Ligesom forgængeren er Nord en komprimeret roman, som er opbrudt i kortprosa-agtige tekstflader ('kassetekster'), som skaber rudimentære og fortættede tids- og rumbilleder, som suspenderer 'plot' i så høj grad, at fortællingen undermineres (mens motivtæthed og metaforiske betydningsniveauer tiltager).

Til gengæld har Nord en tydelig postapokalyptisk metafysik vævet ind i sig, og den stiller to ubehagelige spørgsmål: Hvordan er det muligt at leve i ruinerne af en 
civilisation? Er det i det hele taget muligt? For Nord er en postapokalyptisk roadroman om tre menneskers rejse mod det uspecificerede sted "Nord", fortællerens hjemstavn, men i endnu højere grad transporterer den læseren ind i et fremmedartet sprog og et udpræget poetisk landskab. Nord låner et lyrisk jeg og et sf-sprog (som ganske paradoksalt også er en historisk sprogform) til at beskrive livet efter apokalypsen. Så i stedet for tydeligt at vise en dystopisk subtekst vil jeg læse Nord som en sf-roman, hvor traditionelle lyriske figurer og greb (metaforik, synæstesi, besjæling osv.) står centralt. Dette spor er i min optik ikke marginalt; Nords format og sprog fremstår som en apokalyptisk sf-roman, der beder læseren om at forestille sig et liv hinsides nutidens erfaringsmuligheder og (selv)forståelsesmekanismer fra en forestillet fremtid, hvor der ingen fremtid findes.

Dette postapokalyptiske sprog er et billedligt og ikke mindst besjælende sprog, som skal puste liv ind i en død verden. Det er tekstens centrale organiserende greb og på samme tid en udforskning af totemistiske tendenser i en verden, hvor behovet for at tale er nedprioriteret til fordel for kampen for livsnødvendigheder: anskaffelse af mad og husly, at forsøge at undgå lovløse kriminelle og bevarelsen af menneskelighed. Som W.J.T. Mitchell argumenterer for i artiklen "Romanticism and the Life of Things: Fossils, Totems, and Images", symboliserer et totem ikke kun en urgammel verden. Det er også et billede på selve undergangen: "The totem is the image of a vanishing, endangered life, the trace of a world disappearing" (Mitchell, s. 178).

Nord udforsker et sådant relationelt forhold mellem det totemistiske og apokalyptiske i et lyrisk sf-sprog, som, læst gennem Seo-Young Chus Do Metaphors Dream of Literal Sleep? A Science-Fictional Theory of Representation (2011), fremstår som et forsøg på at fremmane tanke- og sansemåder, der tager læseren hinsides de tilgængelige repræsentationsmåder. Chu læser sf som en type tekst, som kan overskride dikotomien mellem bogstaveligt og figurativt sprog, fordi den er en form for kodificeret tekst, hvor fortolkningen af bogstavelighed og figurlighed ikke fungerer på samme måde som i realistisk litteratur. Hun låner sætningen "Her world exploded" af Samuel R. Delany som et eksempel, der demonstrerer, hvordan figurlighed i sf bogstaveliggøres: Sætningen ville i en realistisk roman blive fortolket metaforisk, men i sf kan glober og planeter - bogstaveligt talt - eksplodere (s. 27).

Lindstrøms billedsprog har desuden en utopisk ansats. Både i og omkring de kataklysmiske undergangsbilleder genindfører den besjælende figurlighed en mytisk tilstand, hvor apokalypsen endnu ikke er en realitet. Fortællerens utopi er nemlig "en slags halvdrøm, der skjønnhet ikke er så umulig" (Lindstrøm, 179). Begrebet 'halvdrøm' er en god indgang til romanen, hvis centrale spænding er den, som opstår i det retoriske dobbeltsyn - tekstens bogstavelige og figurative niveauer - hvor landskabet glimtvis er ødelagt og i glimt lever intenst.

Jeg begynder med en redegørelse for min læseposition og romanens mange genrekontekstuelle muligheder, før jeg går ind i analysen af dens retorik. Herefter følger en komparativ perspektivering til Cormac McCarthy, som bruger et lignende sf-sprog i sin postapokalypse The Road (2005), inden jeg afslutningsvis diskuterer postapokalypse-litteraturens karakteristiske brug af poetisk sprog. 
Fablens form og dystopiens sted

A more ambitious fable will not merely express a truth graphically and memorably, but mainly will generate and store new meaning in the conception it represents H.J. Blackham, The Fable as Literature, s. xii

Før romanens postapokalyptiske poesi undersøges, bør dens format og genre-tilhørsforhold diskuteres kontekstuelt. Om genreplacering udtalte Lindstrøm selv ved udgivelsen: "Det er en dystopi. Og så har jeg vært opptatt av fabler mens jeg skrev" (Stava). Det er ikke fablens moral, Lindstrøm refererer til her, men "det underlige og eventyraktige" ved fablen, altså det fantastiske og fabelagtige ved at natur og dyr kan tale som mennesker. Men Nord er ikke en fantastisk tekst. Romanens fortæller, en ung mand, har ganske vist udvækster på ryggen, som beskrives som "vinger" og "finner", så han fremstår metaforisk som en engel eller avatar i civilisationens ruiner, hvor han med sit lille rejsefølge følger vejen mod nord. Men Lindstrøm placerer sine krigsoverlevende i dybt realistiske situationer, hvor hverdagen er et nulsumsspil: overlev eller gå under. Det fabelagtige må undersøges andre steder i romanen.

Nord er heller ikke episk som en fabel, den består af stemningsbilleder, stedsbeskrivelser og erindringsblokke fra livet før, under og efter "krigen". ' At Lindstrøm alligevel har tænkt romanen som en fabel, bliver tydeligt i mange af dens bestanddele. ${ }^{2}$ Ordet 'fabel' betyder i aristotelisk forstand arrangementet af begivenheder i en fortælling (gr. mythos), men Lindstrøm skriver ikke konventionelle fortællinger, hun låner hellere fablens genrerammer, hvor teksten kan bevæge sig ud af en snæver mimetisk form og ind i en metaforisk. Ifølge H.J. Blackham kører en fabel på "narrative rails", den er en "forlænget metafor", idet der i fablen præsenteres et niveau, hvor det giver mening, at dyr og natur kan tale og tænke på menneskelig vis. Læseren bliver af dette dobbeltsyn hele tiden skubbet op på et niveau, hvor det fantastiske bliver meningsfuldt, fordi figurerne her ikke skal forstås bogstaveligt. Nord er også en sådan "forlænget metafor" (Blackham, xiii), men som jeg snart vil argumentere for, er metaforen mere kompleks hos Lindstrøm, den er nemlig ikke primært analogisk. Den syntetiserer betydning frem for at skabe analogier.

Mangfoldig betydningsproduktion er for Blackham for så vidt også et væsenstræk ved fablen, som han ikke definerer som en genre, men som et narrativt greb og "a tactical manoeuvre to prompt new meaning” (s. xi). Læseren skal altså selv kunne tolke en fabel ud fra et bogstaveligt forlæg, men fortolkningen er ikke givet i og med det bogstavelige niveau. Eksempelvis: Ulven spiser ganske vist lammet ved åen, og skovhuggeren fælder træerne til et nyt skæfte til øksen i La Fontaines fabler, men moralen i disse fabler er det op til læseren at udlede. En entydig morale er ikke givet på forhånd, for fablens metaforiske togskinner leder paradoksalt nok ikke betydningen i rette linjer; de genererer en narrativ betydning, som kræver fortolkning. ${ }^{3}$ Det er i dette perspektiv, vi skal læse Nord, hvis metaforiske greb lader teksten sige mere end det bogstavelige forlæg.

Fablens metaforiske karakter opløser for Blackham tekstens denotative muligheder og forstærker dens konnotative, eftersom metaforer ikke har en fast betydning. Denne forståelse af figurlighed deler han med Paul Ricœur, som i sit teoretiske 
værk The Rule of Metaphor (La métaphor vive, 1975) fremfører samme argument. Blackhams og Ricœurs metaforforståelse har meget at tilbyde i en læsning af Lindstrøms roman, som kan betegnes som en fabel, hvor de metaforiske niveauer distribuerer betydning, som divergerer fra det bogstavelige. Nord har helt sikkert metaforiske lag også som dystopi betragtet: På romanens bogstavelige niveau finder vi postapokalypsen og dystopien, mens vi i fortællerens sprog finder utopiske ansatser, drømme om et bedre sted. Nord er imidlertid ikke så simpelt konstrueret, at den kan opdeles i to, for den består af en række vendinger og fordoblinger, af brud, forvekslingsfigurer og konvergenser mellem figurer, niveauer, stemmer og motiver.

Lindstrøms dystopi-karakteristik bør også kontekstualiseres. Romanen skal ikke læses som en satirisk samfundsroman. Det dystopiske viser sig snarere i romanens scenografi og kulisser (romanens baggrund). Gennem udførlige beskrivelser af landskab og steder langs vejen mod nord hensættes læseren til det dystopiske (gr. dys, 'dårlig' og topos, 'sted'), en del af sf-genren hvor et fiktivt samfunds eller steds sociale, ideologiske og kulturelle orden fremhæves som problematisk i en æstetisk konfiguration. ${ }^{4}$ Denne mekanisme genfinder vi også i Nord, men med romanens vage stedskolorit destabiliseres genrerammerne hele tiden, og i stedet sker en blanding af scenarier og tidsbilleder, uden at det ene prioriteres fremfor det andet (jf. Moes frustrerede vurdering).

Som vi snart skal se, bor det dystopiske også i mange af de figurer og metaforer, som Lindstrøm lancerer i romanen. De giver læseren associationer til popkulturens postapokalyptiske scenarier fra de mange billeder af efterverdenen i film og tv-serier fra 2000-tallet (Mad Max, (Fear) The Walking Dead, Wall-E, The Book of Eli, med flere). Nords diffuse kultur- og tidskolorit er naturligvis fremskrevet bevidst, romanen trækker veksler på både fremtidsscenarier og historiske modeller og aktiverer således et dobbeltsyn også i genreøjemed: Fiktionens opdigtede sted - det dystopiske samfund - er på samme tid både ubehageligt velkendt og befriende nyt. Et sådant dobbeltsyn, dog ikke i forhold til genre, er den primære interesse i denne artikel. Herfra fortsætter vi med romanen og dens retoriske mønstre.

\section{Romanens figurlighed}

Når vi på denne måde bevæger os fra kontekst til tekst, skal romanens æstetik og retorik understreges. Den følgende tekstflade er på flere måder repræsentativ for Nord:

4 Minnene er også på vandring, forlatt i en by, i hus og kjellere, eller strødd langs veien. De tilhører ikke noen lenger, de er kulisser, hjemløse som et skuespill, fotografier av fremmede ansikter blir lagt fram der man håper noen kan gjenkjenne dem, alt som har verdi samles opp i store lagre, i kasser, og blir fordelt, en gulltann, et lite, innrammet speil, et par sko, fine kjoler. Søndagsettermiddager. Glockenspiele. Hårlokker. Et munnspill som tilhører et barn. (s. 32)

Passagens korte sætninger (“Søndagsettermiddager. Glockenspiele. Hårlokker”) og sætningsled ("forlatt i en by, i hus og kjellere") er organiseret i metonymiske op- 
remsninger, som metaforisk konvergerer i fortællerens indre. I denne kaotiske erindringskonfiguration samles spredte dele og bidder, blandt andet i metaforisk form ("Minnene er også på vandring," "de er kulisser"). At motiverne kan optræde som stikord, uden forklarende kontekstualisering i en tekstflade, viser os, at fortælleren forsøger at samle det, som er vilkårligt spredt i erindringen, i en beretning. Apokalypsen har vitterligt opløst alle fortidige forbindelser og sammenhænge, sådan at virkeligheden kan sammensættes på ny $i$ sproget. Fragmenteringen og atomiseringen af minder, erfaringer og indtryk skal modarbejdes i erindringens og konfigurationens samlende funktion.

Den metaforiske prosa i Nord, som hele tiden sammenstiller forskelligartede elementer, er først og fremmest drevet af en poetisk skildring af de tre vandreres rejse på tomme maver blandt truende enklaver med soldater, mellem udbombede landsbyer, rådnende dyrekadavere, lig og traumatiserede krigsofre. Romanens postapokalyptiske motiver bliver fremstillet som figurationer i fortællerens sprog. Betragtninger om død og undergang - og hverdagsforeteelser - bliver eksempelvis til poetiske besjælinger af typen "vindkastet får tak i stemmen når han snakker" (s. 19), og i personifikationer og simili à la "stemmene som gnagde gjennom rommene i bevisstheten som rottene gjennom veggene i leirbrakkene" (s. 46). Nord udvikler hurtigt sin egen galopperende figurlighed, hvor et prosaisk sprog erstattes af et poetisk. For eksempel bliver beskrivelsen af en menneskemængde til "Da vi var en sverm, en sverm i bevegelse" (s. 16), og den smerte fortælleren oplever, da han opsøger minderne om interneringslejren, får poetiske konturer, hvor figurligheden bliver kendetegnende for stilen: "Alt jeg ikke vet, som ofte brenner som et gnagsår, ikke på utsiden, men under huden, langt inne" (s. 109).

Kan uvisheden være et gnavsår? Kan et gnavsår brænde - på indersiden af huden? Ikke bogstaveligt. Beskrivelsen af fortællerens ulmende uro og uvished synes også at være en slags kamp med sproget, som om de metaforiske beskrivelser af fortællerens indre opleves utilstrækkelige, således at det ene billede efter det andet skabes i et forsøg på at beskrive præcist, hvad uroen går ud på, uden at det lykkes. De mislykkede fors $\emptyset$ g genererer imidlertid stadig nye billeder, og denne billedskabende evne til at gøre det abstrakte konkret og det tingslige organisk, kendetegner det overvældende billedsprog i Nord, som viser sig i et utal af billeder, hvor bestemte fænomener formidles i bestemte retoriske former. Ofte bliver krigens traumer og rædsler afbilledet som sår eller (u)dyr: "Smerten har revet seg løs, blitt et udyr og fortsetter for seg selv, ser ikke ut til å forsvinne, men formeres, selv her den ikke hører hjemme" (s. 131).

Besjælingen i romanen peger, som i en fabel, i retning af det Lakoff og Johnson kalder "ontological metaphors", altså de troper og figurer, som organiserer virkeligheden, således at fænomener og objekter kodes med menneskelige egenskaber: 'Inflation er fjenden' osv. (Lakoff og Johnson, 26 og 34). Sprog og erfaring interagerer altså med hinanden i besjælingen, det ydre og abstrakte kan ikke kun betragtes som udvendige, fjerne ting; de får deres funktion og fremtræden i et anvendt litterært sprog, som definerer og ændrer perspektivet på virkeligheden. Hos Lindstrøm er det som regel naturen, som besjæles og tillægges bestemte egenskaber: "Skogen har skjøvet de lave åsene unna, og på den andre siden, der skogen åpner seg, er det 
sletter og enger" (s. 14). Besjælingen af naturen ("har skjøvet", "åpner seg”) er en vending fra passivitet til et aktivt liv. Jeg vender tilbage til dette senere.

Besjæling er en metafor, som helt tydeligt er en fusion af to separate forestillinger, en syntese. Som Ricœur hævder i The Rule of Metaphor, hvor han bygger på I.A. Richards metaforteori fra 1936, er det syntese, ikke lighedsrelation og sammenligning, som er metaforens kendetegn. Ricœur hævder, at vehiklet og tenoren ikke kan læses som separate dele af metaforen, men må tænkes sammen, fordi de i figurationen gensidigt påvirker hinanden. ${ }^{5}$ De deler heller ikke helt de samme karakteristika. Et metaforisk led består af fænomener, som ikke konvergerer fuldstændig (Ricœur, 94), så han foreslår, at metaforen i stedet for at understrege lighed (resemblance) og lave sammenligning (comparison) i stedet laver et betydningsoverskud, hvor spændingen mellem metaforens to dele sikres, og sammenligningen netop af den grund udebliver. For eksempel består udtrykket 'træernes fingre' af to dele, der ikke er helt kongruente - fænomenerne 'fingre' (vehikel) og 'grene' (tenor) er ikke ens - og når de sættes sammen, danner de en legering, som er figurationens egentlige identitet og betydning: Træet menneskeliggøres. Metaforen udvider dermed tekstens betydningsmuligheder.

Konsekvensen af denne måde at tænke metafor bliver, at vi i stedet for at læse Nord som en analogiproducerende tekst med et 1:1-forhold mellem fænomen og sprog, bogstavelighed og figurlighed, forstår den som en tekst, hvor fænomenerne - eksempelvis træer og fingre - ikke forbliver uberørte af den metaforiske transaktion ("does not remain unchanged by the action of the metaphorical utterance," Ricœur, 102). Langs en sådan læseakse kan man argumentere for, at Nords metaforiske karakter destabiliserer læserens forståelse af det postapokalyptiske landskab. Figurligheden skaber en verden, hvor bogstavelighed og figurlighed løber parallelt gennem teksten, men hvor den figurative merbetydning adskiller sig fra den bogstavelige og tilfører den en kompleks fremmedhed, som komplicerer fortællerens og læserens erfaring af den. Figurligheden beriger og udvider teksten, men i den ontologiske forskydning af betydning træder den verden, som Lindstrøm via sin fortæller beskriver, frem som en fluktuerende, flakkende verden - det ødelagte, postapokalyptiske møder sit kontrapunkt i et besjælet, levende sted.

\section{En figurativ "virkelighed"}

Metaforens opgave i Lindstrøms roman er legio, men at der foregår en konfiguration af motiver (hus, mad, mennesker og skov), hvor motiverne antager fordoblet karakter, er tydeligt. De mange stilistiske operationer i Nord skaber en spænding mellem det bogstavelige og det figurative i næsten hver eneste tekstflade. For det første er rejsen mod nord i det ruinerede landskab lige så meget en rejse i fortællerens indre landskab (som er næsten lige så ødelagt som det ydre). For det andet er formatet dobbelt, idet romanen både er en roman og en kortprosasamling, samtidig med også at være både fabelagtig og dystopisk, realistisk og impressionistisk; fortællingen er både personbunden og alvidende; drengen i rejsefølget viser sig at være en pige; nord er både en realitet i kompasset og en utopi i fortællerens forestilling; landskabet er både fænomenalt og imaginært; karaktererne har flere navne etc. Så- 
danne fordoblinger kommer til udtryk i en række mærkværdige formuleringer: "Du finner det nok ut, sier hun, gutten" (s. 170), som der står, efter at fortælleren har opdaget, at rejsepartneren egentlig er en kortklippet ung kvinde.

Set $\mathrm{i}$ et mere traditionelt genreperspektiv er romanen også dobbeltladet i de dystopiske beskrivelser af landskabets elendighed. Via retoriske figurer og troper træder motiverne frem og skaber billeder af en døende verden, ved at de mange natur-, bygnings- og madmotiver i teksten vises frem i synekdokisk form: Mad er nedskaleret til tørre brødskorper og fordærvet kød, skoven er rådden og askegrå, husene er gennemhullede af artilleri og skudsalver, og menneskene er reduceret til lig, kropsdele og omvandrende klude. Fortællerens erindringer om kvinden, som skjulte ham under krigen, Aneska, udtrykkes i formuleringer som synekdokisk kobler krop og tøj sammen i vendinger som "hun er en grå kjole på en kleshenger" og "Aneska er en kjole" (begge citater s. 46). I én scene er fortælleren reduceret i en grad, så han bliver til "en kravlende haug av pyjamas, filler, oppkast" (s. 46). I en analepse erindrer han sine medfanger "som nylagt møkk der på veien" (s. 9), altså afføring, og drengen i rejsefølget omtales som "en tekst med bare ett avsnitt" (s. 22).

Denne form for repræsentation - menneskene i Nord er aldrig hele mennesker, men figurative repræsentationer af en fragmenteret helhed - ses overalt. Blandt andet bliver dyr portrætteret både metaforisk og metonymisk, gerne i en og samme sætning: "Snart er hesten bare en fille over et gammelt skjelett" (s. 101). Sådanne beskrivelser er ikke kun figurative, de får også dystopiske træk, idet de viser, hvor udarmet og svag - døende - romanens verden er. Dens mangfoldighed er reduceret til ruiner og rester. Også de få overlevende fragmenteres i fortællerens metaforiske sprog til punkter og detaljer i større mønstre: "Dagslyset maler oss, vi er en flue som har spasert over en malerpensel og landet midt i landskapet på lerretet" (s. 151). Umenneskeliggørelsen ("vi er en flue") og passivformen ("maler oss") afviser alle forestillinger om menneskelig autonomi og autenticitet, og den samme figurative nedskalering gælder fortælleren. Han lider af en slags traumatiseret skizofreni og opdigter et alter ego ved navn "Jol", som han fører samtaler med undervejs (mens Aneska kaldte ham "Martin" under krigen). I en ekstern analepse finder vi ud af, at han har spaltet sig selv i to, fordi "ensomheten holdt ikke ut seg selv lenger og skapte en annen, men helt lik, oftere og oftere var jeg to" (s. 19). I simili, besjælinger og personificeringer spaltes sansninger i dobbelte figurer, og flere af fortællerens refleksioner er veritable ophobninger af figurlighed, hvor personifikationer og synekdoker optræder parallelt: "Hjelpeløsheten og besluttsomheten kranglet i ansiktstrekkene" (s. 104).

Eftersom denne metaforicitet er så overvældende, kan den ikke læses som en isoleret del af Nord, den skal forstås som romanens primære organiserende greb. Men hvordan har forfatteren selv organiseret figurligheden? At systematisere alle de forskellige sprogbilleder er nytteløst, men teksten kan konceptualiseres ved at se på de motivkæder, som optræder mest hyppigt - mennesker, dyr, natur og bygninger, samt tid- og rum-markører. Eksempelvis bliver tid næsten konsekvent beskrevet i rumlige og visuelle metaforer, som enten er relativt konventionelle ("Ukene forsvinner" og "dagene trengte seg sammen" (s. 46 og s. 9)) eller udpræget poetiske: "Da dagene begynte å få tid igjen og ikke lenger var en tjukk og tåket konsistens" (s. 
34). Også årstider, lys og mørke beskrives gennem besjæling: "natta banker lyset ut av dagen, av de grå markene, den hatske, slitne himmelen" (s. 108).

Også fortællerens efterhånden udsultede krop bliver reduceret til dele og stykker. I en spejlrefleksion antropomorficeres han i sit eget blik: "Skuldrene til en mager geit, beinete gammelmannsfingre" (s. 11). Her smelter det menneskelige ("skuldrene") sammen med det dyriske ("mager geit"), som igen koder det sidste sætningsled i refleksionen ("beinete gammelmannsfingre") med en imaginær alderdoms svækkede fysik i en spektakulær billedlig fremstilling af et sulteoffer. I denne retoriske fordobling opstår en poetisk transmission mellem bogstavelighed og figurlighed, som medfører, at fortællerens blik kæder bygninger og kroppe sammen: "Jeg er et hus," sier han, "men noen ganger er jeg bare et tomt hus, hvem som helst kan komme inn døra, bo her, den som vil" (s. 122). Disse metaforiske ytringer skaber et billede af karakteren for læseren og fortæller samtidig, at han er et let offer for omgivelserne, en beholder og et hjem for krigsomgivelserne, som hele tiden forsøger at "bebo" ham med vold, frygt og sult.

Hus-motivet bliver i øvrigt gentaget og fungerer impressionistisk, ved at observationerne til stadighed peger tilbage på beskueren i form af kraftesløshed og livløshed; formuleringerne "de sjelløse husene langs veien" (s. 18) og "skjelettet av et forlatt hus" (s. 108) fungerer både som billeder på generel tomhed og forladte huse $o g$ som billede på fortælleren, hvis blik altid spejler sig i landskabet. Lindstrøm fremmaner således et ødelagt individ og et sanset sammensat landskab, hvor læseren mere end noget andet ser en oplevelse af landskabet snarere end landskabet-isig-selv. Landskabet i Nord er altid et landskab i overført betydning. Metaforiciteten i sproget virker altså på to niveauer og omdanner i virkeligheden fænomenologiske huse til billeder på fortællerens indre tilstand. Læserens opmærksomhed vendes i disse transaktioner fra det bogstavelige til det figurative, altså fra det litterære motiv til dets metaforiske overskud, hvor merbetydningen er den vigtige. Her er det ikke analogier, der opstår, men nærmere ekstravagante overskridelser i billeder, som giver læseren et mere intenst udtryk af fortællerens smertefyldte tilværelse.

I dette dobbeltsyn forstyrres det mimetiske, således at ellers stabile forhold som subjekt-objekt og indre-ydre forstyrres med en intensitet, som en realistisk prosa næppe kunne have formidlet: "Kroppen min hadde en stemme, en myk stemme som sang og falt, mens det var jorda som jamret eller skreik" (s. 15). Hvordan skal vi forstå "stemme" her? Sådanne paradoksale metaforer kan kun forstås intuitivt og figurativt, ved at læseren er i stand til at forestille sig, at fortællerens skrig er en metafor for en mere grundlæggende lidelse, som i denne poetiske beskrivelse: "Barnet står ved enden av gjerdet, ansiktet skriker, stemmen er like stille som alt det andre" (s. 29). Hvordan ser et skrigende-tavst ansigt ud? Kroppene "skriker" ofte i oxymoroner i Nord. Sådanne umulige formuleringer gør den kropslige lidelse (sult, nød, traumer) i romanen langt mere angstbetonet end en prosaisk, bogstavelig beskrivelse af et skrig ville kunne gøre. Et realistisk formsprog er ikke tilstrækkeligt til at beskrive en postapokalyptisk smerte.

Det figurative sprog i Nord er en retorisk og æstetisk konsekvens af den dystopi, som Lindstrøm skitserer: en verden revet i stykker af menneskets barbariske tilbøjeligheder. Retorisk og æstetisk synes det billedlige sprog i romanen at dulme lidelsen 
ved at forskyde en forventet realistisk beskrivelse af den, men i realiteten giver den bare læseren en anderledes, figurativ tilgang til den. Ricœurs tese om figurativ fremstilling gælder her: "[T] o figure is always to see as, but not always to see or to make visible" (Ricœur, s. 70). I dette formsprog fusioneres poetisk sprog og en sf-forestilling, det er trods alt en fortælling om livet efter en apokalypse, det handler om. Vi kunne sige, at Lindstrøm tyer til poetiske figurer for at kunne tematisere og formidle en postapokalyptisk tilstand, hvor en realistisk prosa virker uhensigtsmæssig.

Denne tematik er udgangspunktet i Seo-Young Chus Do Metaphors Dream of Literal Sleep (2011), hvor hun læser sf som en slags litteratur, der er drevet af lyriske og poetiske kræfter (Chu, 10). Vi tænker oftest sf i narrative termer, skriver hun, blandt andet, kunne man tilføje, fordi så mange associerer sf med ideer, tendenser og ikke mindst fænomener som world building: skabelsen af verdener og fænomener som endnu ikke findes (aliens, rumskibe, tidsrejser, kunstig intelligens). Men sf er direkte poetisk, hævder Chu, som påpeger, at både lyrik og sf er en type vending, altså en trope og et forsøg på at fremskrive et fænomen, som ligger udenfor samtidens sprog og erfaring. Al sf-tekst har denne karakter eller i det mindste enkeltstående øjeblikke og scener, hvor robotten får sin egen vilje, klonen taler, rumvæsener kigger på mennesker eller en planet kommunikerer telepatisk med astronauter.

I denne optik bliver sf ifølge Chu en genre som er "counterliteral and counterfigurative," altså en type tekst hvor det er svært at skelne det bogstavelige og det figurative: "Like the metaphor, SF is counterliteral: both metaphor and SF bring into imagined existence things nonexistent in the world of literal facts" (s. 68). De synæstetiske og poetiske billeder hos Lindstrøm synes i dette perspektiv at pege mod en apokalyptisk bevidsthed, som skal transportere læseren til et sted og en tilstand, han/hun ikke har erfaring med. I motiverne (bogstavelige) af træer, hud, hænder, huse, synekdokiske dele og rester, trækkes tråde til oversanselige betydninger (figurative) som tilsammen giver læseren en postapokalyptisk fornemmelse, som går ud over sansningens domæne. Appellen og affekten ved sådanne vendinger er, hævder Chu, ikke så meget rettet mod det cerebrale som det kropslige, mod det som med kun stor vanskelighed lader sig repræsentere:

6 By empowering SF to operate beyond the opposition between the counterfigurative and the counterliteral - by allowing lyric figures in SF to operate on a literal level without losing their figurative power - the absent omnipresence of lyric enables SF to represent objects and phenomena normally averse to representation. (Chu, 68)

Dette problem med repræsentation overvinder Lindstrøm - for at beskrive en verden, der er gået til grunde, som jo ligger hinsides ethvert menneskes erfaringshorisont - med sine mærkelige billeder af fortælleren, der vandrer igennem et wasteland. Men med skabelsen af sådanne billedsprog opstår et problem med fortolkningen. Billedernes mangfoldige muligheder for fortolkning er som sagt en berigelse af teksten, men det bliver vanskeligt at afgøre, hvad romanen gerne vil formidle. I et forsøg på at systematisere nogle af billederne og motiverne og udlede betydning fra, hvordan de bliver organiseret, vil jeg nu kigge på det tydeligste retoriske dobbeltsyn i Nord, nemlig besjælingen. 


\section{Det besjælede landskab}

Landskabet besjæles allerede i romanens første tekstflade, hvor fortælleren bemærker at "trærne hvisker eller vinker mot lyset" (s. 7). Flere anmeldere kommenterede Nords besjælede sprog, men kun antydningsvis, så en begrebsafklaring er her på sin plads. ${ }^{6}$ Besjæling er retorisk set en stilfigur, men foruden en brug af det ornamentale har den, som metafortype, også en syntetiserende funktion ved at repræsentere "analogien, dobbeltvisjonen, det sanselige bildet som røper det umerkelige, og den animistiske projisering," som det hedder i et oversat citat fra Wellek og Warren i Lyriske strukturer (Kittang og Aarseth, 87). ${ }^{7}$ Udover at antyde en dobbelthed og organisere teksten retorisk, har animistiske og antropomorfe operationer som besjæling, apostrofe og personifikation også et mytisk element, idet de rummer et ønske "om å gi det ukjente og ukontrollerbare et ansikt som kan gjenkjennes" (s. 90). Kittang og Aarseth tilskriver figuren en bestemt funktion: Den skal ophæve afstanden mellem subjekt og objekt, mellem beskueren og det som beskues.

Eftersom besjælingen tilskriver fænomener bestemte tanker, følelser eller egenskaber, giver den fænomenerne et karakteristisk indhold, som styrer karakterens erfaring og læserens fortolkning. Men hvilken styring? Her bliver Lindstrøms fabelinspiration nok engang synlig, hun låner besjælingsretorikken fra en mytisk tid, da mennesker organiserede sig i stammer og klaner med hver deres egne rutiner, vaner og ritualer; inklusiv sproglige. I mytisk sprogbrug fungerer besjælingen, som Wellek og Warren er inde på, som erstatningsgreb for det, som ikke skulle udtrykkes. I jødedommen er Gud den unævnelige, som må metaforiseres til en sten, sol eller løve, men det er ikke kun frygt som skaber metaforer: "We metaphorize also what we love, what we want to linger over and contemplate, to see from every angle and under every lighting, mirrored in specialized focus by all kinds of like things" (Wellek and Warren, 197).

Fortællerens animistiske projicering i Nord kan også have en sådan erstatningsfunktion, men den skal mest forstås som et forsøg på at indgyde landskabet et liv, som apokalypsen ødelagde. Projektionen skal overskride sit analoge mandat, blandt andet tildeles skovens træer rollen som beskytter eller som kærlig forælder, som varmt omfavner liv: "Jeg liker skogen som holder rundt noe, trærne vokter innsiden, og det er stille" (s. 12), og "greinene holder rundt oss, i armhulene gjemmer det seg ekorn og feite ugler" (s. 14). Skoven repræsenterer i disse citater en mytisk verden, hvor "trærne hvisker ned gjennom de gamle strupene sine og får oss til å gå i nye sirkler, tette som årringer, rundt og rundt, det er den eneste bevegelsen de kjenner, trærne" (s. 98).

Som ved et verbalt trylleslag bliver skoven en levende kontinuitetsbærer ("rundt og rundt") og forbindelsesled til det før-apokalyptiske. Skoven får en totemistisk karakter. Som Mitchell skriver, er totemet i sig selv symbol på fastholdelsen af en forsvindende verden. Den nære relation mellem sprog og sprogbruger ekspliciteres i Nord, idet fortælleren indlemmer sig selv i skovmetaforikken i et slags drømmesyn, hvor hans indre verden væves sammen med den ydre:

46 Ofte tenker han at han er et tre. Han er bare ikke helt ferdig ennå, han har greiner som 
av alt han allerede kjenner og er vant til (han ble jo plantet her, ett av flere trær), se inn av vinduene, når det regner kan han se sitt eget rom, forestille seg at han fortsatt er der inne, sitter i senga, ved arbeidspulten, hører foreldrene i de andre rommene. Når han ser trær, kjenner han seg roligere, det ville ikke forstyrre ham, skremme ham, å være et tre. (Lindstrøm, 57)

Passagens motiv kommer muligvis som et symptom på fortællerens splittede, traumatiserede psyke - romanen har mange skizofreni-motiver - men samtidig forklarer billedet, hvorfor objekter generelt og træer specielt stadig dukker op med "fingre" og "arme" i hans fortælling. ${ }^{8}$ De menneskelige attributter i det tilbagevendende billede "træernes fingre" påkalder fortællerens tabte, menneskelige fællesskab. I genopstået, besjælet form gives naturen en bestemt egenskab, når de askegrå træer menneskeliggøres. Verden, som den var engang, er nu genoprettet, og fortælleren er på ny indlemmet i et naturligt fællesskab ("han ble jo plantet her," "han har greiner,"), hvor træernes fredelige nærvær repræsenterer den tryghed, som gik tabt i ødelæggelsen.

Besjælingens dobbelthed har meget tilfælles med totemismen, som Freud mente var et grundlæggende socialt organiseringsprincip for stammen i førmoderne tid, før religionen nedfældede symboler skriftligt og institutionelt (Freud, 158). Totemet, som oftest et dyr, kan defineres som et billedligt udtryk for klanen eller stammen, det repræsenterer fællesskabets identitet og blev tilbedt religiøst og rituelt. Gruppen definerede sig selv i kraft af totemets metonymisk repræsentative egenskaber eller metaforiske attributter, der syntetiserer relationer mellem mennesker og dyr/ting: Totemismens figurative relations-skabelse sporer vi i Nord, hvor natur og træer metaforiseres som fortællerens "stamme". Ordet stamme er en gentaget polysemi, som ikke er uden betydning i romanen, da den antyder både træets urokkelige søjle og menneskets genealogi. Denne antydede konvergens danner fortællerens (metaforiske) forbindelse til et liv før apokalypsen. Totemismen i Nord er imidlertid ikke fuldt og helt et stammeopråb, da fortælleren synes afskåret fra slægt og familie; hans to rejsevenner, drengen og barnet, bliver hans nye fællesskab og familie, men de deler ikke hans affinitet for totemistisk tale.

I romanens naturmetaforik skal totemismen genetablere en tilværelse, hvor livet er udholdeligt, og fællesskabet stadig intakt. Eftersom der ikke findes en meningsfuld fremtid i postapokalypsen, er fortiden og mindet om den det eneste halmstrå. I udbombede huse langs vejen mod nord oplever fortælleren, at han bliver betragtet, idet: "trærne står i vinduet og ser på oss fremmede, som pleide å bo i hus" (s. 98). Den humaniserende besjælings omvending genopretter - i utopiske konfigurationer - den nærhed med omgivelserne og fællesskabet, som apokalypsen udraderede. Man skulle tro, at den totemistiske naturbesjæling gjorde romanen harmonisk og nostalgisk, men romanens fortættede kortprosa-karakter tillader ikke langvarig retrospektion. I stedet strækkes besjælingen ud som en modreaktion på apokalypsens brutalitet til den også omfatter andre ting end træer, for eksempel kulturelt producerede fænomener.

Besjælingen bliver i Nord en til tider totaliserende romanfiguration, hvor selv militærfly "med den tjukke magen og de fulle tarmene som tømmes ut i åssiden," der 
har "revet ned trærne gjennom vintermånedene, hele åssiden har revner og flenger etter treffene," (s. 7) optræder. Med denne antropomorfisering opstår det antagonistiske forhold mellem natur og maskine, som en række kanoniske dystopier etablerer, ikke. I stedet for en enkel dikotomi mellem naturlig og unaturlig skaber besjælingens syntese muligheden for, at alle eksisterende fænomener kan indgå i et utopisk fællesskab. Eftersom apokalypsen i romanen kommer i form af en udryddelseskrig af folkemordslignende omfang, udtrykker animeringen af maskiner, huse og træer i romanen formodentlig fortællerens desperate behov for at se sig selv $i$ en helhed, hvor alt potentielt kan inkluderes.

Det ser imidlertid ikke ud til, at animeringen opretholdes i romanen. Da barnet forlader rejsefølget mod slutningen af romanen, og den unge kvinde vender sig mod skoven for at finde svar eller trøst, vinder realiteterne over projektionerne: "Hun snur seg likevel mot trærne bak oss, som om de kan si noe om ungen" (s. 189). Sætningsleddet "som om" angiver ganske vist en figuration, men det indikerer samtidig, at sammenligningen mellem træer og mennesker ikke længere opretholdes. Efter at den besjælede natur har været lige så vigtig som den fænomenale, svarer den nu kun med ligegyldig tavshed. Det figurative spil i romanen er mere eller mindre ovre, og dystopien er fuldbyrdet. Skismaet mellem mennesker og ting - blikket og det, blikket fanger - genoprettes.

Dette sene brud i teksten er imidlertid varslet tidligt. Allerede i tekstflade \#2 har fortælleren ubevidst afsløret, at besjælingen udelukkende var en retorisk akt. Efter at have observeret "drengen" i et træ - romanens første sætning - stiller han sig op og pisser på et nærtstående træ. "Treet hadde en munn," bemerker han, "et mørkt hull på størrelse med neven min" (s. 8). Til trods for den metaforiske projektion kan træet ikke tale, og i stedet fyldes træets "munn" med pis. Motivet er altså både spaltet og syntetiseret - delt op som et objektiveret træ, besjælet som et menneskeliggjort objekt, og som en natur, som i overført betydning drukner på grund af menneskelig indgriben. Motivet er romanens første subtile økokritiske billede, og det fungerer selvfølgelig som et mikrokosmos-billede på apokalypsen: Menneskene pisser på naturen.

I økokritiske motiver som disse anes en dystopisk subtekst i Nord, hvor kritik af forfatterens samtidstendenser synliggøres, men denne subtekst udgør, så vidt jeg kan se, ikke den mest interessante del af romanen. Den dominerende del af romanen er dens figurative spil og dets fortolkningsmæssige implikationer. I artiklens sidste del vil jeg derfor argumentere for, at figurligheden i Nord skaber et poetiseret apokalypsesprog, og derfor fortjener romanen sammenligning med årtusindets mest hyldede postapokalyptiske roman.

\section{Postapokalypsen poetiseret: The Road}

Nord har en række påfaldende ligheder med Cormac McCarthys The Road. Også McCarthy tager fat i fablen, når han beskriver sine vandrere, en far og en søn, i et landskab befolket af mordere, kannibaler, katastrofeofre og lig: "Like pilgrims in a fable swallowed up and lost among the inward parts of some granitic beast" (McCarthy, 3). Fabelmarkøren bliver ikke bare tidligt sluppet ud i teksten, anvis- 
ningen af retorisk figurlighed ("like pilgrims") angiver, at apokalypsen også her afføder et stilistisk rigt sprog. Begge forfattere griber altså til fabelgenren og et mytisk-figurativt sprog, når de opdigter katestrofetableauer. Men hvorfor problematisere en sprogpraksis blandt mennesker i et landskab, hvor verbalsprog er en luksus, og tilværelsen er blevet Darwins værste mareridt?

Fablen har som vist en metaforisk fleksibilitet, som involverer læserens forestilling og indlevelsesevne. Den er en form, som passer godt til det spørgsmål, som en postapokalyptisk roman altid stiller: Hvordan ville vores højt skattede menneskelighed fungere under de mest kummerlige forhold - uden adgang til hjem og mad, uden teknologi, velfærd, tillid og medmenneskelighed? Eftersom postapokalypsen implicerer "the frailty of everything revealed at last," som det hedder hos McCarthy (s. 24), kunne man tro, at også svaret på dette store spørgsmål burde være af samme støbning, altså implicit. Men i modsætning til i Nord bliver svaret eksplicit formuleret i The Road.

Uden faste rammer ritualiserer mennesket sin tilværelse, det skaber ceremonier og talemåder til at fastholde og ordne verden, genskabe den som et meningsfuldt sted "der skjønnhet ikke er så umulig." I førmoderne tider og blandt det, Freud kalder "primitive" folkeslag, havde totemet denne rolle. Efter apokalypsen, som reducerer menneskeheden til atomiserede og primitive kollektiver, antager sproget totemistiske former. McCarthys alvidende fortæller hævder: "Evoke the forms. Where you've nothing else construct ceremonies out of the air and breathe upon them" (s. 63). Den særlige besjæling, som finder sted i begge romaner, er en gentaget genoplivning af gamle sprogformer og -ritualer. Mennesket har i kraft af sproget evnen til at projicere betydning over på sine omgivelser, vække formerne af sin slumren i askeruinerne og indordne kaos i en ceremoniel sprogform, hvor det utydelige bliver tydeligt og det formløse formet. Karaktererne og fortællerne i Nord og The Road låner et symbolsk, figurativt sprog, som samler det, som er knust og spredt; og indenfor ritualets og ceremoniens rammer organiseres, bogstaveliggøres og formgives det, som kræver en form - sorg, savn, kærlighed, religiøs tro.

Påmindelser om vigtigheden af den sproglige formgivning optræder ofte i The Road, som når faren kigger på en skovbrand, som sluger landskabet: "Make a list. Recite a litany. Remember" (s. 27). Samle, ordne, erindre; konfigurere, altså, i sproglig form. Selv en apokalyptisk klagesag kræver en form, som gør den meningsfuld og giver dens iboende smerte legitimitet. Men de to romaners apokalyptiske retorik er forskellig. Som Lindstrøm åbner McCarthy med en stilistisk markør, nærmere bestemt en simile: "Nights dark beyond darkness and the days more gray each one than what had gone before. Like the onset of some cold glaucoma dimming away the world" (s. 3). McCarthys prosa er på samme måde som Lindstrøms marineret $\mathrm{i}$ figurlighed, men førstnævnte ser ud til at opvurdere similen, ikke metaforen.

Det sammenlignende billedsprog i The Road optræder parallelt med bogstavelige beskrivelser af forkullede træer og rådnende lig, hvor similens første led ("days more gray") bekræftes af leddet, som følger sammenligningsordet ("glaucoma dimming"). På samme måde som metaforen er similen også en retorisk fortætning, men i sidstnævnte operation forbindes og analogiseres leddene ved et "som". Hvor Lindstrøm skaber metaforiske fordoblinger, hvor leddene gensidigt påvirker hinanden, er McCarthys simili en anden type dobbeltsyn. Han bruger similen ("Like") til at dele figuren i to, i to separate sætninger: "The black skin stretched upon the bones and their faces split and shrunken on their skulls. Like victims of some ghastly envacuuming" (s. 161). Og: "At night when he woke coughing he'd 
sit up with his hand pushed over his head against the blackness. Like a man waking in a grave" (s. 180). Helsætningen kobles her til en sammenlignende ledsætning, og sammenligningen introduceres med bindeordet "Like". Denne opdeling af figuren skaber ikke bare anskuelighed, men også ontologisk klarhed: Sprogbillederne fortæller, at en anden, parallel verden stadig er mulig i en komparativ dialektik. Man får indtryk af, at der stadig sammenlignes mellem to verdener i McCarthys roman, således at den kongruente lighedsrelation i similen fungerer anskueliggørende i The Road, som i følgende billede: "The nights were blinding cold and casket black and the long reach of the morning had a terrible silence to it. Like a dawn before battle" (s. 109).

Similens lille "Like" skaber et poetisk sprog, hvor "bildets egentlige kjerne og det som bare tjener til å anskueliggjøre eller konkretisere" træder frem, ifølge Kittang og Aarseth (s. 81). Similen opretholder altså forskellen mellem det, som skal forstås bogstaveligt (helsætningen, de kolde nætter og den lange morgen), og det, som figurerer det bogstavelige (den uselvstændige ledsætning, krigens morgengry). I en metafor opstår der derimod en spænding mellem leddene, "hvor begge gjensidig farger hverandre og virker sammen om å skape en selvstendig og ny betydning" (s. 81). Similen har altså ikke metaforens poetiske fortætning. Hvor McCarthy analogiserer ved, at sammenligningsleddet bekræfter og dermed sluger det første led, har Lindstrøms besjælinger fjernet det sammenlignende bindeord således, at lighedsrelationen problematiseres. Metaforiseringer som "bevissthetens ødemark" (Lindstrøm, 21) er nærmere inkongruente størrelser sat sammen i en konfiguration, som skaber forundring og i større grad kræver tolkning. Nord kan derfor betegnes som en retorisk mere kompleks og mere fortættet tekst end McCarthys, hvor landskaberne, både de indre og de ydre, destabiliseres. Det betyder ikke nødvendigvis, at Lindstrøm skriver mere poetisk end McCarthy. Førnævntes æstetiske strategi er at lade de poetiske billeder tale med større tvetydighed, så den postapokalyptiske poesi gør det vanskeligt at tolke billederne.

Hos McCarthy er similienes aktivitet desuden ikke lige så gennemført som metaforiciteten i Nord. Similiene i The Road opleves mere som poetiske pusterum fra undergangsfortællingen, end som en gennemført poetik, næsten som om similens funktion er at gøre undergangen mere udholdelig for læseren. The Road er en lige så kulsort fabel, og McCarthys billeder er distinkt poetiske: "Like the onset of some cold glaucoma dimming away the world" er en diagnostisk-visuel poetisering af, hvordan verden langsomt forsvinder for fortællerens blik: Øjensygdommen antyder, at verden er i færd med at mørknes af asken, der falder fra de brændte træer. I denne regn bliver ikke bare landskabet, men også alle tidligere værdier, moraler og menneskelige hensyn begravet. Similen er dermed podet med moralske implikationer og må læses som romanens første prolepse af det gammeltestamentelige barbari, som senere vises frem i fuld udstrækning.

I begge romaner tilføjer det figurlige sprog postapokalypsen en dimension, som ikke findes på forhånd. Besjælinger og simili danner figurlige mønstre, som genfortryller dystopien i det formelle, og, i dette tilfælde, i det rituelle, ved at begge forfattere indsluser en dystopisk vision gennem et mytisk sprog. Katastrofen i romanerne føder et bestemt sprog som en modreaktion til undergangen, men figurligheden 
skaber også verden på ny. I et vandrende menneskes blik kan en ny verden - i det mindste retorisk set - bygges på asken af den foregående.

\section{"The end is nigh": Sf og poetisk sprog}

Språket fangar, og apokalypsen har fanga oss.

Simon Malkenes, Apokalypse nå igjen? (s. 9)

Nord skriver sig ind i en postapokalyptisk linje i norsk litteraturhistorie, hvor Knut Faldbakkens Uår I-II (1974-76), Georg Johannesens Simons bok (1980) og Jan Roar Leikvolls Fiolinane (2010) er blandt pejlemærkerne. I disse værker, hvor en postapokalyptisk stemning træder frem i den særlige poetiske stemning af sproget, transporteres læseren ikke bare til en tid hinsides sin egen virkelighed, men også til et sprog, som ligger hinsides det, vi kan erfare. Et endnu tydeligere eksempel på postapokalyptisk poesi finder vi i Øyvind Rimbereids SOLARIS korrigert (2004), hvor det delvis dialektale og delvis internationale sprog retarderer betydning for læseren, som må bedrive fortløbende oversættelsesarbejde samtidig med, at de poetiske figurer tolkes.

Ligesom dystopiens opdigtede sted er den opdigtede apokalyptiske retorik også dobbelt. Det er nemlig i sprogliggørelsen af en mulig fremtid, at dystopien har sin egenart som genre, ifølge David W. Sisks Transformations of Language in Modern Dystopias (1997): En dystopisk tekst får læseren til at forstå sig selv og sit samfund ikke kun fra en potentiel, ekstrapoleret fremtid, men fra og $i$ et sprog, hvor kampen om betydning er en vel lige så vigtig konflikt som kampen mod sociale og økonomiske magtstrukturer (Sisk, 169). Dystopien er en sprogkritisk genre, hvor det ikke bare er læserens samfund, der tænkes på ny, men hvor også sproget bruges til at reorganisere en tænkning. Sisk er ikke alene om at påpege dystopiens sproglige interesser (se Raffaella Baccolini og Tom Moylans Dark Horizons. Science Fiction and the Dystopian Imagination).

Hvorvidt sf generelt dermed skal betegnes som en metaforisk genre, som Adam Roberts argumenterer for i sin bog Science Fiction (2006), hvor genrens "sandhed" på Ricœursk vis altid er metaforisk formet, er imidlertid usikkert. En sådan genreteori er absolut gyldig og bør udforskes videre, eftersom den giver sf-forskningen et stærkere retorisk og filologisk mandat, hvor sf læses via poesiens figurlige potentiale for overskridelse, ikke prosaens mimetiske og metonymiske form. Roberts understreger i sin teori den sproglige nyskabelse, vi finder i enhver sf-tekst, hvor "poetry and speculative thought" er forfatterens fornemste våben (Roberts, 144). Udover at bygge på Ricœurs metaforteori trækker han den førnævnte Samuel R. Delanys konceptualisering af sf ind som et "poetic surplus", en forståelse som befinder sig i nærheden af Seo-Young Chus, som jeg har lanceret for at påvise, at sf og poesi er nøje forbundet ved, at de begge er en type vending. I Do Metaphors Dream of Literal Sleep? A Science-Fictional Theory of Representation, hvor Chu gør forbindelsen eksplicit, kan vi derimod forstå denne sprogproblematik helt bogstaveligt.

Apropos sprogproblematik: Meget postapokalyptisk litteratur viser en helt bogstavelig interesse for nysproglighed; vi ser nye sprog blive skabt: kentisk engelsk i Russel Hobans Riddley Walker (1980) og fremtidscockney i Will Selfs i Book of Dave (2006); i Norge er Rimbereid formentlig den fremmeste eksponent for postapokalyptisk poesi med sit sær- 
egene Solaris-sprog. Eksemplerne viser, at i denne genre er sproget ikke bare et instrumentalt kommunikationsredskab eller et ideologisk magtmiddel, men en individuel og kollektiv forståelsesmekanisme for de litterære karakterer såvel som for læseren. Hvis verden ændres, ændres sproget også, og vice versa. At læse sf generelt og Nord i særdeleshed uden at lægge vægt på affiniteten for sprogproblematisering er at negligere teksten som litteratur, som en retorisk og poetisk konfiguration, for eksempel af verdens ende. Apokalypsen, hvad enten den kommer som en krig, pest, brand eller asteroide, kræver et sprog, som gør den forståelig.

For efter apokalypsen kommer nemlig postapokalypsen: Selv efter alle tings ende skal verbalsproglige konfigurationer forme vores ontologi. At virkeligheden konfigureres i metaforer og dermed bliver poetiseret, destabiliserer troen på en ensartet, fælles verden, hvor metaforer skaber betydning - som fabler - fremfor at visualisere og sammenligne. Således argumenterer Terence Hawkes, også med udgangspunkt i I.A. Richards: "A language 'creates' reality in its own image" (Hawkes, 60). Efter konfigurationerne må verdens beskaffenhed diskuteres og genforhandles.

På den anden side åbner denne indsigt for at virkeligheden altid kan genforhandles og fornyes i sproget, som jo er et utopisk initiativ i sf. Genrens - og Nords - bøn om et figurativt sprog demonstrerer, at et rigt sprog skaber alternative versioner og en mangfoldighed af perspektiver på krig, epidemier og apokalypse, hvor den litterære teksts potentiale for poetisk flertydighed og kompleksitet danner udgangspunkt for læserens meddigtende evner. For eksempel ser karaktererne i The Road ud til at have en bevidsthed om sprogets evne til at forme verden. Konen/moderen er allerede $\mathrm{d} ø \mathrm{~d}$, da romanen begynder, og i faderens erindring røbes det, at hun begik selvmord, fordi hun resignerede. Da manden hævder, at de trods alt har overlevet verdens ende, svarer hun: "We're not survivors. We're the walking dead in a horror film" (s. 47). Bliver man først fanget i apokalypsens retorik, er håbløsheden nærliggende.

Faderen og sønnen i The Road kæmper bevidst mod at blive fanget i håbløsheden, for de forstår også sprogets kraft, men med modsat fortegn. Deres mantra "we're carrying the fire" er ikke bare del af en verbalsproglig trøst og et selvopholdelsesmiddel, men også en olympisk understregning af, at deres selvforståelse og selvlegitimering - som lysbærere i en mørk verden - opstår i sproget, og at dette sprog har en rækkevidde, som strækker sig udover det verbale og ind i bevidstheden. Metaforer konsoliderer troen på sprogets vedvarende kraft i en døende verden, således at grænserne i denne digtning skubbes for det, som findes, og det som kunne findes, og giver læseren erfaringer, der ikke er mulige at danne sig udenfor sf.

I et postapokalyptisk læseperspektiv har Lindstrøm med Nord skabt en poesi, som findes efter katastrofen, hinsides de erfaringer, vi er i stand til at have i dag. Og som Chu skriver i sin bog, ligger både postapokalypsen og poesien udenfor tiden, men digterne taler ind i den og til den: "Lyric voices speak from beyond ordinary time" (Chu, 13). Overlevende efter apokalypsen og poeter er antagelig begge "doomed to soliloquy," som hun skriver, men selv i en mørk tid skal der tales, digtes og synges - om den mørke tid, for at parafrasere Brecht. 


\section{Noter}

I Det er også muligt at lave en læsning, der lægger vægt på romanens historiske tendenser. Stednavnene (“Aneska”, "Konstantz", "Alpene” og "Welcherweg”) røber, at vi er i tyskklingende sprogområder, hvor en krig har hærget, og derfor er referencen til 2. verdenskrig nærliggende. Civilisationens ruiner i romanen skaber billeder af et udbombet Europa efter 2. verdenskrig, af epidemier, hungersnød og lovløshed, og romanens fortæller er brændemærket med et fangenummer fra en interneringslejr. Nord er altså også en erindringsroman med en genkendelig historisk reference, hvor fortælleren desperat forsøger at fastholde en flig af fortiden.

2 Blandt andet nævnes pædagogiske genrer og godnathistorier ("Gutenachtgeschichten"), og fortælleren tænker sig selv som en del af en fortælling, blandt andet som en fabelhelt, idet han forestiller sig, at offervilje altid medfører en happy ending. "Den som tør å tape, får belønningen: barnet kommer tilbake, treet var en prins, svanene går på jorda som mennesker igjen" (s. 144). Men fablens logik og narrativ er irreversibilitetens. Fablen understreger en moral gennem pædagogisk opstillede dikotomier (uskyldskyld, ansvarlighed-uansvarlighed, naivitet-kynisme) og uddeler moralske lektioner i metaforisk form. Læringen skal doseres med uigenkaldelig nåde, for at lektionen kan fungere.

3 Se La Fontaine, s. 20-21 og s. 450.

4 I min ph.d.-afhandling EIN systm total (2010) udforsker jeg retorik og æstetik i flere efterkrigsdystopier: Axel Jensens Epp (1965), Gerd Brantenbergs Egalias døtre (1977), Georg Johannesens Simons bok (1980) og Kjartan Fløgstads Det 7. klima (1986) er dystopier, hvor forfatteren lancerer et bestemt sprog, enten for at vise Norge i et fremtidigt troldspejl, som politisk magtmiddel (i romanerne) eller som en oprørsk enklaves utopiske løsrivelsesredskab i kampen mod undertrykkende regimer.

5 Tenoren er den underliggende ide som metaforen udtrykker, mens vehiklen er den grundlæggende analogi som transporterer tenoren.

6 Se Hovdenakk: "Følelsen av ekstrem usikkerhet og utsatthet preger historien, sammen med en tidvis fascinerende besjeling av omgivelser og natur."

7 Hos Wellek og Warren ser citatet således ud: "Analogy; that of double vision, that of the sensuous image; revelatory of the imperceptible; that of animistic projection" (Wellek og Warren, 197).

8 Også bøger besjæles i sætninger, hvor synekdoker ("hender" og "kvister på treet") og besjælinger ("Bøker er triste hender") konvergerer: "Bøkene er triste hender, papiret henger ut som hvite og blå fingre, eller kvister på treet de stammer fra" (s. 194).

\section{Litteratur}

Auklend, Morten (2010): "EIN systm total". Utopier og dystopier i norsk etterkrigstid, ph.d.-afhandling, Bergen: Universitetet i Bergen.

Baccolini, Raffaella og Tom Moylan (2003): Dark Horizons. Science Fiction and the Dystopian Imagination, New York: Routledge.

Blackham, H.J. (1985): The Fable as Literature, London: The Athlone Press.

Chu, Seo-Young (2011): Do Metaphors Dream of Literal Sleep? A Science-Fictional Theory of Representation, Cambridge: Harvard University Press.

Freud, Sigmund (2013): Totem og tabu. Noen overensstemmelser mellom villes og nevrotikeres sjeleliv, oversat af Kari Uecker, Bergen: Vidarforlaget.

Hawkes, Terence (1977): Metaphor, London: Methuen.

Hovdenakk, Sindre (2017): "Dystre tider", anmeldelse, i VG, 4. november 2017.

Kittang, Atle og Asbjørn Aarseth (1998): Lyriske strukturer. Innføring i diktanalyse, Oslo: Universitetsforlaget. 
La Fontaine, Jean de (1988): Fabler, gendigtet af Johannes Møllehave, København: Hernovs Forlag. Lakoff, George og Mark Johnson (2003): Metaphors We Live by, Chicago: The University of Chicago Press.

Lindstrøm, Merethe (2017): Nord, Oslo: Forlaget Oktober.

Malkenes, Simon (2008): Apokalypse nå igjen? Oslo: Det norske Samlaget.

McCarthy, Cormac (2006): The Road, New York: Picador og Alfred A. Knopf.

Mitchell, W.J.T. (2001): "Romanticism and the Life of Things: Fossils, Totems, and Images", i Critical Inquiry 28.1, s. 167-184.

Moe, Kenneth (2017): "For-mye-kontroll-i-kaoset", anmeldelse, i Aftenposten, 11. november 2017.

Ricœur, Paul (2003): The Rule of Metaphor. The Creation of Meaning in Language, London: Routledge. Roberts, Adam (2006): Science Fiction. A Critical Introduction, Second Edition, London: Routledge.

Sisk, David W. (1997): Transformations of Language in Modern Dystopias, Westport: Greenwood Press.

Stava, Gerd Elin (2017): “Nå søker hun nord”, interview, i Dagsavisen, 4. november 2017.

Wellek, Rene and Austin Warren (1956): Theory of Literature. 3. udg., New York: Harcourt, Brace \& World. 